\title{
A comparison of nutritional values and antioxidant levels of desi and Turkish kabuli chickpea (Cicer arietinum L.) seeds
}

\author{
Tuğçe KALEFETO ĞLU MACAR ${ }^{1}$ (D), Oksal MACAR ${ }^{1, *}$ \\ ${ }^{I}$ Giresun University, Şebinkarahisar School of Applied Sciences, Department of Food Technology, Giresun / TURKEY
}

\begin{abstract}
Chickpea has an increasing importance due to potential as a functional food. This study aimed to compare three kabuli genotypes (Gülümser, Sarı and Arda) with three desi genotypes (ICC 3996, Gaffa and ICC 12004) considering nutrients and antioxidant capacity. Therefore, nutritional values of seeds were analyzed in terms of tota 1 protein, carbohydrate and mineral element contents, while total phenolic and total flavonoid contents besides ABTS and DPPH radical scavenging capacities were tested to investigate antioxidant capacities. Kabuli genotypes were superior to desi genotypes considering seed weight, seed volume and hydration capacity. All genotypes except ICC 3996 were rich in protein. Despite its small seeds, ICC 3996 genotype was identified as the richest genotype according to carbohydrate content. ICC 3996 and Arda had superiority over other genotypes according to ABTS and DPPH antioxidant capacities. Sarı and Gülümser were determined to be superior to other genotypes according to phenolic and flavonoid contents. Desi genotypes were superior to kabuli genotypes considering $\mathrm{Ca}, \mathrm{Na}, \mathrm{Mg}, \mathrm{Fe}$ and $\mathrm{Cu}$ contents, while $\mathrm{Mn}$ and $\mathrm{Ni}$ contents were significantly higher in kabuli seeds. The results of the study showed that all genotypes can be accepted as functional food, supported by rich nutritional values and mineral contents.
\end{abstract}

\author{
Article info \\ History: \\ Received: 08.07.2020 \\ Accepted: 17.11 .2020 \\ Keywords: \\ Antioxidant, \\ Cicer arietinum L., \\ Desi, Kabuli.
}

\section{Introduction}

Chickpea (Cicer arietinum L.) is an annual grain legume belonging to Cicer genus, Fabaceae family, Papilionaceae sub-family and Cicereae tribe [1]. It is the unique cultivated plant among the 43 wild (9 annual and 34 perennial) species in Cicer genus [2]. Self-pollination and diploid cells with $2 \mathrm{n}=16$ chromosomes are the other important features of the species [3]. The first cultivation of chickpea took place in the Fertile Crescent 10,000 years ago. South-eastern region of Turkey is accepted to be the most possible gene centre of chickpea [4]. Considering the worldwide cultivation area (14.6 M ha), chickpea is the second most produced pulse crop mostly grown in arid/semi-arid regions [5]. The global popularity of $C$. arietinum mostly depends on its protein-rich seeds. In addition to rich protein content, chickpea seeds are inexpensive and easily accessible foods for human and animal nutrition, as they are good sources of carbohydrates [6]. The seeds are free from cholesterol, low in fat and contain large amount of fiber, folate, $\beta$ carotene, vitamins and minerals including calcium, magnesium, phosphorus, zinc and iron [7, 8]. Its outstanding nutrient content makes chickpea seeds important for the nutrition of vegetarians and people who cannot afford animal protein. In addition to its nutritional properties, cooking quality is an important criterion for consumers to prefer dried legume seeds. Physical characteristics of chickpea seeds including weight, density and hydration capacity can affect cooking quality [9]. On the other hand, chickpea has a special importance for sustainable agriculture in nitrogen-poor soils. According to chickpea fallow trials, symbiosis with bacteria for nitrogen fixation allows the crop to fix $60-103 \mathrm{~kg} \mathrm{ha}^{-1}$ nitrogen to the fields [7].

Chickpea genotypes are classified as "desi" or "kabuli" according to characteristics of their seeds. Desi type chickpea has small and dark coloured seeds with thickrough coat, while kabuli type has large seeds with thin and light coloured coat [10]. The two genotypes are so different that desi has pink flowers and a stem with anthocyanin pigmentation, while kabuli has white flowers and anthocyanin-free stem [11]. Kabuli chickpea, which is thought to be derived from the mutation of desi type, is mainly grown in Mediterranean region, Central Asia and America. On 
the other hand, desi type is mainly cultivated in India and several regions of East Africa [12]. Turkey is among the most important chickpea producers with 630,000 tons of annual production and per capita consumption of chickpea is $5.8 \mathrm{~kg}$ per year in Turkey [5].

Legumes are substantial sources of biologically active compounds with influential antioxidant, anticancer and antiaging capacities [13]. However, the literature on the antioxidant capacity of chickpea seeds is extremely weak. Therefore, the aim of this study was to compare the nutrient contents and antioxidant capacities of desi and kabuli chickpea genotypes, as well as their physical properties. For this purpose, protein, total carbohydrate and element content were investigated in chickpea genotypes. Antioxidant capacities of different seeds were screened utilizing total phenolic and flavonoid contents and 2,2'-azinobis(3ethylbenzthiazoline-6-sulfonic acid) (ABTS ${ }^{+}$) and 1,1diphenyl-2-picrylhydrazyl $\left(\mathrm{DPPH}^{+}\right)$radical scavenging potentials.

\section{Materials and Methods}

\subsection{Preparation of materials}

Three kabuli (Sarı, Arda, Gülümser) and three desi (Gaffa, ICC 3996 and ICC 12004) chickpea genotypes (Figure 1) provided by Eastern Mediterranean Agricultural Research Institute, Adana, Turkey were used in this study. The names of the genotypes were coded as KS (Sar1), KA (Arda), KG (Gülümser), DG (Gaffa), D39 (ICC 3996) and D12 (ICC 12004). Kabuli genotypes bred and registered by Turkish researchers were selected especially based on large and lightcolored seeds. Desi genotypes were randomly selected for different seed colors and sizes to represent the class of interest. 300 seeds from each genotype were selected in approximately equal sizes. Seed surfaces were sterilized with $2 \%$ sodium hypochlorite solution to remove pesticide residues and other contaminants. Following the sterilization procedure, the seeds were rinsed three times with distilled water.

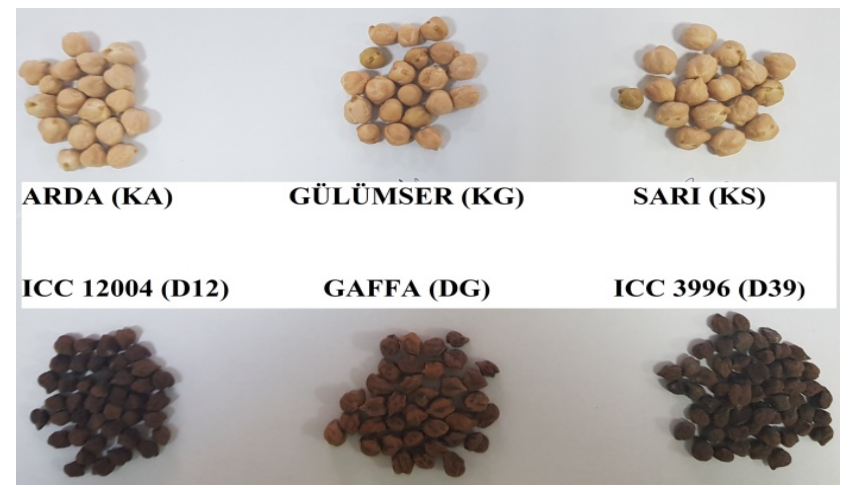

Figure 1. Seeds of kabuli and desi types.

\subsection{Determination of physical characteristics}

Physical properties of seeds were evaluated according to the method mentioned by Zia-Ul-Haq [14]. 50 seeds were randomly selected for each genotype and weighed to determine the mean seed weight $(\mathrm{g} / \mathrm{seed})$. 100 seed were soaked in a $100 \mathrm{ml}$ flask filled with 50 $\mathrm{ml}$ distilled water. Seed volume $(\mathrm{ml} / \mathrm{seed})$ was calculated by dividing the volume increase by 100 . Seed density $(\mathrm{g} / \mathrm{ml})$ was obtained through dividing seed weight by seed volume. Seeds were kept in distilled water for 24 hours following weighing and the hydration capacity (gr/seed) was determined from the increase in weight at the end of the period. The hydration index of seeds was calculated by dividing the hydration capacity by the original seed weight. All analyses were repeated three times.

\subsection{Determination of protein content}

Total protein content of seeds was determined according to Biuret method [15]. Seeds were grounded into powder with a grinder following 24 hours of imbibition period in distilled water. $0.5 \mathrm{~g}$ chickpea flour was extracted in $1.5 \mathrm{ml}$ potassium phosphate buffer $(0.1 \mathrm{mM}, \mathrm{pH}=7.5)$. Standard curve was prepared with $0.1-1.0 \mathrm{mg} / \mathrm{ml}$ bovine serum albumin. Total protein contents of extracts were measured spectrophotometrically at $540 \mathrm{~nm}$ wavelength and calculated as $\mathrm{mg} / \mathrm{ml}$ using the calibration curve. All analyses were repeated three times.

\subsection{Determination of carbohydrate content}

The total carbohydrate content was determined by the method proposed by Hedge and Hofreiter [16]. Seeds were powdered with a grinder following 24 hours of imbibition in distilled water. Glucose stock standard, working standard, anthrone reagent and $2.5 \mathrm{~N}$ hydrochloric acid was prepared for the analysis. 100 $\mathrm{mg}$ glucose was dissolved in $100 \mathrm{ml}$ water to prepare glucose stock standard and $10 \mathrm{ml}$ stock was diluted to $100 \mathrm{ml}$ to obtain working standard. Anthrone reagent was freshly prepared through dissolving $0.2 \%$ anthrone in ice-cold concentrated sulfuric acid. $100 \mathrm{mg}$ chickpea flour was transferred to a boiling tube and the sample was hydrolysed by boiling the tube containing $5.0 \mathrm{ml}$ $2.5 \mathrm{~N} \mathrm{HCl}$ for three hours. The tube was then cooled to room temperature and neutralized with solid sodium carbonate until bubbling stopped. The volume of the mixture was completed to $100 \mathrm{ml}$ and the mixture was filtered with Whatman no.1. Standard curve were prepared using $0.2-1.0 \mathrm{ml}$ working standards. $4.0 \mathrm{ml}$ of anthrone reagent was added to $1 \mathrm{ml}$ sample, and the mixture was boiled for eight minutes. Then, the mixture was cooled immediately. The green-dark green colour of the extracts was read on the 
spectrophotometer at a wavelength of $630 \mathrm{~nm}$. Distilled water was used as a blind. All analyses were repeated three times.

\subsection{Determination of element contents}

Contents of twenty-five elements were accomplished by Central Research Laboratory Application and Research Center in Giresun University. Seed samples were prepared used the microwave wet digestion method before the analysis. Element levels of seeds were screened with the method Inductive Coupled Plasma Mass Spectrometry (ICP-MS; Bruker 820-MS, Germany). All analyses were repeated three times and the results were given as $\mathrm{mg} / 100 \mathrm{~g}$ seed. Sodium $(\mathrm{Na})$, potassium $(\mathrm{K})$, calcium $(\mathrm{Ca})$, magnesium $(\mathrm{Mg})$, manganese $(\mathrm{Mn})$, zinc $(\mathrm{Zn})$, iron $(\mathrm{Fe})$, copper $(\mathrm{Cu})$, lithium (Li), beryllium (Be), boron (B), aluminum $(\mathrm{Al})$, vanadium $(\mathrm{V})$, chrome $(\mathrm{Cr})$, nickel $(\mathrm{Ni})$, gallium $(\mathrm{Ga})$, selenium $(\mathrm{Se})$, rubidium $(\mathrm{Rb})$, strontium $(\mathrm{Sr})$, molybdenum (Mo), cadmium $(\mathrm{Cd})$, barium $(\mathrm{Ba})$, thallium $(\mathrm{Tl})$, lead $(\mathrm{Pb})$ and uranium $(\mathrm{U})$ elements are determined.

\subsection{Determination of phenolic and flavonoid contents}

Seeds were imbibed in distilled water for 24 hours and powdered mechanically. Phenolic and flavonoid extraction were performed according to the method suggested by Marinova et al. [17]. $0.5 \mathrm{~g}$ chickpea flour were transferred to ultrasonic bath for 20 minutes in 50 $\mathrm{ml}$ of $80 \%$ methanol for extraction.

$2 \mathrm{ml}$ of extract was collected for phenolic and flavonoid assays [17]. The total phenolic content was evaluated using the supernatant obtained by centrifugation at $14,000 \mathrm{rpm}$ for 5 minutes according to the Folin - Ciocalteu method. $9 \mathrm{ml}$ of distilled water and then $1 \mathrm{ml}$ of Folin-Ciocalteu reagent were added to $1 \mathrm{ml}$ of extract. The tube was shaken for 5 minutes. 10 $\mathrm{ml}$ of $7 \% \mathrm{Na}_{2} \mathrm{CO}_{3}$ and $4 \mathrm{ml}$ of distilled water were added to the tube which was then shaken at room temperature for 90 minutes. All steps were repeated for gallic acid solutions (20-100 $\mathrm{mg} / \mathrm{l})$ to prepare a standard curve. The absorbance of the samples and standard solutions was read spectrophotometrically at $750 \mathrm{~nm}$. The results for the total phenol content were calculated and expressed as mg gallic acid equavalents (GAE/100 g seed).

Flavonoid assay was carried out according to aluminium chloride colorimetric method [17]. $4 \mathrm{ml}$ of distilled water and then $0.3 \mathrm{ml}$ of $5 \% \mathrm{NaNO}_{2}$ were added to $1 \mathrm{ml}$ of extract. The tube was shaken for 5 minutes. $0.3 \mathrm{ml}$ of $10 \% \mathrm{AlCl}_{3}$ and $2 \mathrm{ml}$ of $1 \mathrm{M} \mathrm{NaOH}$ were added to the mixture at intervals of 5 minutes. Finally, $2.4 \mathrm{ml}$ of distilled water was put in the mixture. The flask containing the reaction mixture was quickly shaken. All steps were repeated for catechin solutions $(20-100 \mathrm{mg} / \mathrm{l})$ to prepare a standard curve. The absorbance of the samples and standard solutions was read spectrophotometrically at $510 \mathrm{~nm}$. The results for the total flavonoid content were calculated and expressed as mg catechin equavalents (CE/100 g seed). All steps for phenolic and flavonoid assays were repeated for three times.

\subsection{Determination of radical scavenging capacity}

ABTS and DPPH radical scavenging potentials were performed according to Thaipong et al. [18]. $3 \mathrm{~g}$ chickpea flour was kept in ultrasonic bath for 30 minutes in $25 \mathrm{ml}$ of methanol for homogenization. The homogenates were centrifuged for 20 minutes at $15,000 \mathrm{rpm}$ after waiting 12 hours at $4{ }^{\circ} \mathrm{C}$ and the supernatant portions were collected for antioxidant potential analysis.

Two stock solutions were prepared, one of which was $7.4 \mathrm{mM} \mathrm{ABTS}^{+}$and the other was $2.6 \mathrm{mM}$ potassium persulfate. The reaction mixture was prepared by mixing the stock solutions in equal proportions. The reaction solution was kept at room temperature in a dark chamber for at least 12 hours. Then, $60 \mathrm{ml}$ of methanol was added to dilute $1 \mathrm{ml}$ of $\mathrm{ABTS}^{++}$solution. Dilution was continued until reaching $1.17 \pm 0.02$ absorbance at $734 \mathrm{~nm}$ in the spectrophotometer. $150 \mu 1$ of extract was mixed with $2850 \mu 1$ of $\mathrm{ABTS}^{+}$solution and the mixture was left to react in the dark for 2 hours. The absorbance of the mixture was read at $734 \mathrm{~nm}$. The results of $\mathrm{ABTS}^{+}$radical scavenging activity were calculated using the standard curve prepared with 25$600 \mu \mathrm{M}$ Trolox solutions according to the equations given below (1):

$\mathrm{ABTS}^{+}$radical scavenging activity $(\%)=[(\mathrm{A} 0-\mathrm{A} 1) / \mathrm{A} 0] \times 100$

A0: Absorbance of the control.

A1: Absorbance of the sample and standard [18]. 
$24 \mathrm{mg}$ DPPH was dissolved in $100 \mathrm{ml}$ methanol for preparing the stock solutions. $1.17 \pm 0.02$ absorbance at $515 \mathrm{~nm}$ was obtained in the spectrophotometer by mixing $10 \mathrm{ml}$ of stock solution with $45 \mathrm{ml}$ of methanol. $150 \mu 1$ of extract was mixed with $2850 \mu 1$ of DPPH solution and the mixture was allowed to react in a dark chamber for 24 hours. The results of DPPH radical scavenging activity were calculated using the standard curve prepared with 25-800 $\mu \mathrm{M}$ Trolox solutions according to the equations given below (2).

DPPH radical scavenging activity $(\%)=[(\mathrm{A} 0-\mathrm{A} 1) / \mathrm{A} 0] \times 100$

A0: Absorbance of the control.

A1: Absorbance of the sample and standard [18].

The results of ABTS and DPPH analyses were given as sample quantities capable of clearing $50 \%$ of ROS (IC50)

\subsection{Statistical analysis}

The results of the analysis were statistically tested with ANOVA using SPSS software and compared using a significance level of $\mathrm{P} \leq 0.05$.

\section{Results and Discussion}

Table 1 reflects the physical features of desi and kabuli seeds. Kabuli seeds were heavier than desi types. The seed weights of KS, KA, KG, DG, D39 and D12 were

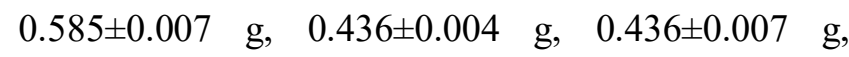
$0.228 \pm 0.003 \mathrm{~g}, 0.145 \pm 0.001 \mathrm{~g}$ and $0.156 \pm 0.001 \mathrm{~g}$, respectively. While the heaviest genotype was KS, the lightest genotype was D39. Kabuli genotypes were superior to desi genotypes in terms of seed volumes similar to seed weights. The seed volume of KS $(0.46 \pm 0.001 \mathrm{ml})$ was significantly more than other genotypes. DG $(0.20 \pm 0.007 \mathrm{ml})$ had the most seed volume among desi seeds. Genotypes with the lowest seed volume were D39 and D12. Kabuli and desi types could not been distinguished precisely considering the seed density results. The highest seed density was determined in D12 $(1.300 \pm 0.010 \mathrm{~g} / \mathrm{ml})$, while DG $(1.179 \pm 0.026 \mathrm{~g} / \mathrm{ml})$ had the lowest seed density. Hydration capacities of kabuli seeds were notably

Table 1. Physical characteristics of kabuli and desi seeds. higher than desi types. KS was determined to be superior to other genotypes in terms of hydration capacity $(0.596 \pm 0.005 \mathrm{~g})$, similar to seed weight and seed volume. Our results were in accordance with Kaur and Singh [19] who stated that the seed weight and volume of kabuli types were more than desi types. Hydration capacity of D39 $(0.136 \pm 0.001 \mathrm{~g})$ was significantly lower than those of other genotypes. In addition, the sorting of the genotypes according to their seed weight and hydration capacities are similar. Our data on maximum and minimum levels in hydration capacity of the seeds were lower than those noted by Özer et al. [9]. Seed size is known to be a major factor for water absorption capability of legumes [20]. Kaur and Singh [19] reported a strong positive correlation with the hydration capacity and the seed mass, similar to our results. A higher hydration capacity may be due more permeable seed coats. The results of hydration index of the genotypes were very close to each other. However, the hydration index of kabuli genotypes was higher than those of desi genotypes. The least hydration index was detected in D39 $(0.941 \pm 0.006)$. Lower hydration capacity and hydration index were previously pointed out as reflectors of an impermeable and hard coat [21].

\begin{tabular}{cccccc}
\hline GENOTYPE & $\begin{array}{c}\text { Seed weight } \\
(\mathrm{g})\end{array}$ & $\begin{array}{c}\text { Seed volume } \\
(\mathrm{ml})\end{array}$ & $\begin{array}{c}\text { Seed density } \\
(\mathrm{g} / \mathrm{ml})\end{array}$ & $\begin{array}{c}\text { Hydration capacity } \\
(\mathrm{g})\end{array}$ & $\begin{array}{c}\text { Hydration } \\
\text { index }\end{array}$ \\
\hline KS & $0.585 \pm 0.007$ & $0.46 \pm 0.001$ & $1.271 \pm 0.014$ & $0.596 \pm 0.005$ & $1.019 \pm 0.003$ \\
KA & $0.436 \pm 0.004$ & $0.36 \pm 0.007$ & $1.232 \pm 0.013$ & $0.466 \pm 0.005$ & $1.069 \pm 0.003$ \\
KG & $0.436 \pm 0.007$ & $0.34 \pm 0.007$ & $1.258 \pm 0.031$ & $0.464 \pm 0.012$ & $1.066 \pm 0.043$ \\
DG & $0.228 \pm 0.003$ & $0.20 \pm 0.007$ & $1.179 \pm 0.026$ & $0.226 \pm 0.003$ & $0.993 \pm 0.010$ \\
D39 & $0.145 \pm 0.001$ & $0.12 \pm 0.001$ & $1.205 \pm 0.003$ & $0.136 \pm 0.001$ & $0.941 \pm 0.006$ \\
D12 & $0.156 \pm 0.001$ & $0.12 \pm 0.001$ & $1.300 \pm 0.010$ & $0.153 \pm 0.001$ & $0.981 \pm 0.001$ \\
\hline
\end{tabular}


Protein content in cereals such as wheat is only $10 \%$ of dry weight, while protein rate in legumes can be reach to $20-40 \%$ [22]. The total protein content of genotypes ranged from $15.51 \mathrm{mg} / \mathrm{ml}$ to $29.73 \mathrm{mg} / \mathrm{ml}$ (Figure 2). KS was the richest genotype with respect to the total protein content. KA $(22.11 \mathrm{mg} / \mathrm{ml})$ had the lowest protein level among kabuli genotypes.

Summo et al. [23] reported that brown (desi) chickpeas were distinguished by a lower amount of proteins when compared to kabuli chickpeas. However, there was no significant difference between the total protein amounts of $\mathrm{KG}$, a kabuli genotype, and $\mathrm{DG}$, a desi genotype in our study. The least protein content was found in D39, a desi type. Jadhav et al. [24] stated that the total protein content of chickpea seeds varied from $17 \%$ to $24 \%$ of the seed dry seed weight of desi and kabuli. Protein content of our seeds with an exception of D39 was similar to those of Jadhav et al. [24]. In another study with different desi and kabuli seeds, similar to the results of this study, D39 was shown to have the lowest protein content [25]. Sarika et al. [26] stated that there was an inverse relationship between seed weight and protein content. However, our results clearly showed that KS, the heaviest seed, also had the highest protein content.

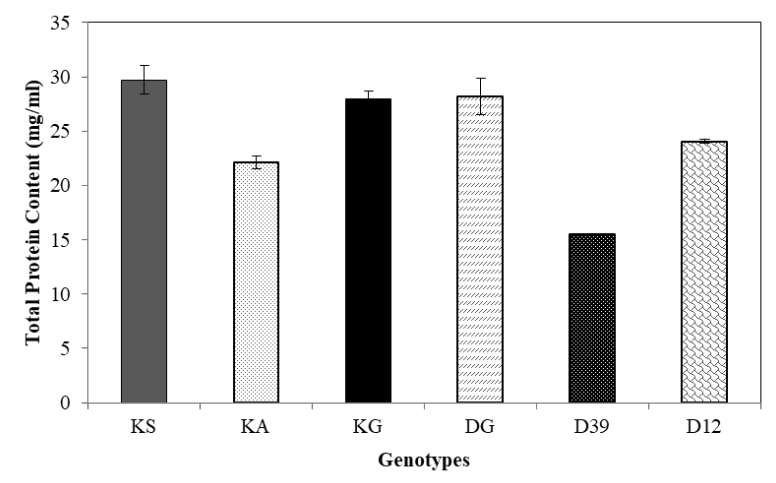

Figure 2. Total protein content of kabuli and desi chickpea seeds.

Legume seeds are characterized by high protein and carbohydrate content (15-68\%) and are defined as foods with a low glycemic index. Indeed, carbohydrates stored at cotyledons are the most abundant components of chickpea seeds [27]. The total carbohydrate contents of desi and kabuli genotypes were given at Figure 3. Although all genotypes were found to be rich in carbohydrates, D39 $(33.33 \pm 0.75)$ had the most abundant carbohydrate content. The least carbohydrate amount was determined in KA $(27.63 \pm 1.25)$. Different results are shown in the literature regarding the carbohydrate content of desi and kabuli chickpea seeds. Swamy et al. [28] reported that higher levels of total carbohydrate were determined in kabuli seeds. Another study indicated that the carbohydrate storage capacity in desi seeds was quite large [29]. Wang et al. [30] stated that starch amount in chickpea seeds elevated with increasing seed weight. However, the current study showed that genotypes with low seed weight also had considerable total carbohydrate storage.

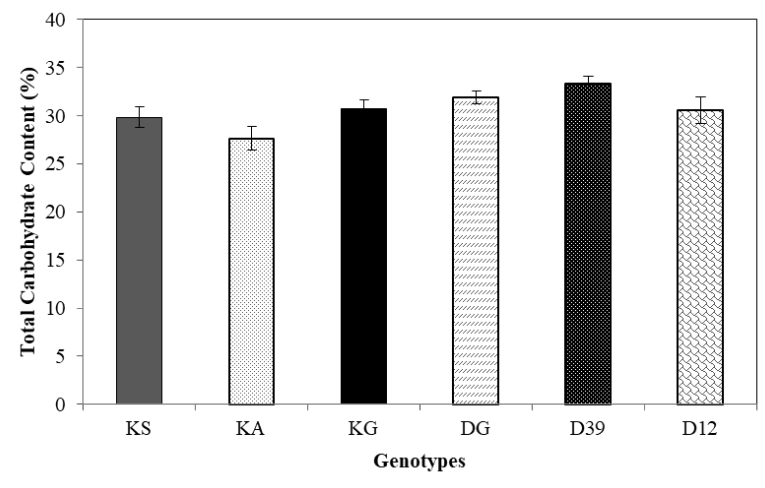

Figure 3. Total carbohydrate content of kabuli and desi, chickpea seeds.

More than 3 billion people in the world experience various health problems due to mineral deficiency associated with malnutrition [31]. Mineral deficiencies are tried to be overcome with mineral-rich natural functional foods or mineral-enriched supplements [32]. With its rich mineral content, chickpea promises potential as an important functional food. A total of 25 different elements were determined in desi and kabuli type seeds (Table 2). In terms of nutritional value, the results of the elements that are known to be prominent compared to other elements were discussed. It was determined that desi genotypes had a distinct advantage over kabuli genotypes in terms of $\mathrm{Na}$ element. Na amounts in DG, D39 and D12 genotypes were $\quad 12.1729 \pm 0.0175 \mathrm{mg} / 100 \mathrm{~g}$ seed, $14.86583 \pm 0.0250 \mathrm{mg} / 100 \mathrm{~g}$ seed and $11.2149 \pm 0.0184$ $\mathrm{mg} / 100 \mathrm{~g}$ seed, while the amount of $\mathrm{Na}$ in $\mathrm{KA}, \mathrm{KG}$ and KS varieties were listed as $6.5746 \pm 0.0097 \mathrm{mg} / 100 \mathrm{~g}$ seed, $4.7475 \pm 0.0078 \mathrm{mg} / 100 \mathrm{~g}$ seed and $4.1731 \pm 0.0081 \mathrm{mg} / 100 \mathrm{~g}$ seed. On the contrary to our results, Ghribi et al. [33] reported that Tunisian kabuli varieties contained significantly higher $\mathrm{Na}$ amount than Tunisian desi genotypes. The genotype with the highest $\mathrm{K}$ element was KA $(1240.3860 \pm 1.6085$ $\mathrm{mg} / 100 \mathrm{~g}$ seed) and the lowest was the D39 $(1004.9330 \pm 1.6793 \mathrm{mg} / 100 \mathrm{~g}$ seed). Similar to our results, Zia-Ul-Haq [14] showed that desi genotypes from Pakistan had K amounts ranged from $1109 \pm 4.49$ $\mathrm{mg} / 100 \mathrm{~g}$ seed to $1272 \pm 7.821109 \mathrm{mg} / 100 \mathrm{~g}$ seed. It was determined that $\mathrm{Ca}$ and $\mathrm{Mg}$ elements were found more in desi genotypes than kabuli genotypes. Limit values in cultivated chickpea seeds were determined as $68-269 \mathrm{mg} / 100 \mathrm{~g}$ for $\mathrm{Ca}, 230-1272 \mathrm{mg} / 100 \mathrm{~g}$ for $\mathrm{K}$, $0.31-11.6 \mathrm{mg} / 100 \mathrm{~g}$ for $\mathrm{Cu}$ [34]. Therefore, all the 
genotypes used in the study drew a profile very close to the upper limit given for $\mathrm{Ca}$. Furthermore, our genotypes were much richer than the limits given in terms of $\mathrm{K}$ level. Our data on $\mathrm{Mg}$ amounts in desi and kabuli seeds were higher than those (56.44-132.27 $\mathrm{mg} / 100 \mathrm{~g}$ seed) mentioned before by Kaur et al. [35]. Varshney et al. [7], confirming our results, pointed out that chickpea was quite rich in magnesium and calcium. The amount of $\mathrm{Mn}$ was higher in kabuli genotypes than those in desi genotypes. The richest genotype according to $\mathrm{Mn}$ was $\mathrm{KG}$ (4.0584 \pm 0.0058 $\mathrm{mg} / 100 \mathrm{~g}$ seed) and the poorest genotype was D12 (1.2682 \pm 0.0020$)$. The $\mathrm{Zn}$ content was $4.3794 \pm 0.0047$ $\mathrm{mg} / 100 \mathrm{~g}$ seed in KS, followed by KA (3.3228 \pm 0.0033 $\mathrm{mg} / 100 \mathrm{~g}$ seed) and D39 $(3.1565 \pm 0.0045 \mathrm{mg} / 100 \mathrm{~g}$ seed) genotypes. Limit given for $\mathrm{Mn}$ and $\mathrm{Zn}$ in cultivated chickpea seeds were $1.78-5.16 \mathrm{mg} / 100 \mathrm{~g}$ and 2.2-20 mg/100 g, respectively [34]. Mn amount of all genotypes except DG and D12 were between given limits. In all of our genotypes, $\mathrm{Zn}$ amounts were within the range of reported limits. In terms of $\mathrm{Fe}$ and $\mathrm{Cu}$ element content, seeds of desi genotypes were richer than seeds of kabuli genotypes. While the genotype with the highest Fe content was D39 $(19.99 \pm 0.0189$ $\mathrm{mg} / 100 \mathrm{~g}$ seed), the lowest genotype was KA (11.1698 $\pm 0.0089 \mathrm{mg} / 100 \mathrm{~g}$ seed). Kaur et al. [35] stated that kabuli and desi genotypes had 4.59-9.87and 4.56-9.83 $\mathrm{mg} / 100 \mathrm{~g}$ seed Fe content, respectively. Fe content of all the genotypes examined in our study was far above the values reported in the study mentioned. Kayan and
Adak [36], verifying our results on all genotypes, stated that chickpea seeds were rich in zinc, calcium, magnesium, potassium and iron. The richest genotype in terms of $\mathrm{Cu}$ was D39 $(1.7267 \pm 0.0022 \mathrm{mg} / 100 \mathrm{~g}$ seed), while the poorest genotype was KA $(0.9691 \pm 0.0022 \mathrm{mg} / 100 \mathrm{~g}$ seed). Our results were in accordance with the study of Jambunathan and Singh [37] who reported that $\mathrm{Cu}$ levels of kabuli and desi seeds were $0.8-1.4$ and $1.0-2.1 \mathrm{mg} / 100 \mathrm{~g}$ seed, respectively. According to Ray et al. [38], the most frequent mineral deficiency affecting the human health globally was iron, zinc, potassium, calcium, nickel and selenium. However, magnesium, manganese, nickel and selenium deficiencies are also at a considerable level. In the current study, considering Ni element content, genotypes were listed as D39 $(0.2330 \pm$ $0.0010 \mathrm{mg} / 100 \mathrm{~g}$ seed), D12 (0.1922 $\pm 0.0009 \mathrm{mg} / 100$ $\mathrm{g}$ seed), DG $(0.1771 \pm 0.0011 \mathrm{mg} / 100 \mathrm{~g}$ seed $), \mathrm{KG}$ $(0.7302 \pm 0.0011 \mathrm{mg} / 100 \mathrm{~g}$ seed $), \mathrm{KS}(0.5890 \pm 0.0013$ $\mathrm{mg} / 100 \mathrm{~g}$ seed $)$ and KA $(0.4866 \pm 0.0008 \mathrm{mg} / 100 \mathrm{~g}$ seed). There was no significant difference between the Se element content of DG and D12 seeds. The genotype with the highest Se content was KA (0.8196 $\pm 0.0007 \mathrm{mg} / 100 \mathrm{~g}$ seed) and the lowest one was KS $(0.6692 \pm 0.0002 \mathrm{mg} / 100 \mathrm{~g}$ seed $)$. The differences between the mineral elements of the genotypes may vary depending on the soil, agricultural practices and climate characteristics of the geography where the seeds are grown as well as the genetic features of the varieties.

Table 2. Element content of kabuli and desi seeds.

\begin{tabular}{|c|c|c|c|c|c|c|}
\hline \multirow{2}{*}{$\begin{array}{l}\text { Element } \\
(\mathrm{mg} / 100 \mathrm{~g} \text { seed })\end{array}$} & \multicolumn{3}{|l|}{ Kabuli } & \multicolumn{3}{|l|}{ Desi } \\
\hline & KA & $\mathrm{KG}$ & $\mathrm{KS}$ & DG & D39 & D12 \\
\hline $\mathrm{Na}$ & $6.5746 \pm 0.0097$ & $4.7475 \pm 0.0078$ & $4.1731 \pm 0.0081$ & $12.1729 \pm 0.0175$ & $14.86583 \pm 0.0250$ & $11.2149 \pm 0.0184$ \\
\hline $\mathrm{K}$ & $1240.3860 \pm 1.6085$ & $1144.2160 \pm 1.7236$ & $1087.8280 \pm 1.9375$ & $1091.2500 \pm 1.5466$ & $1004.9330 \pm 1.6793$ & $1062.6810 \pm 1.6824$ \\
\hline $\mathrm{Ca}$ & $120.0545 \pm 0.1592$ & $150.6436 \pm 0.2584$ & $166.8246 \pm 0.3087$ & $254.7075 \pm 0.3716$ & $208.7302 \pm 0.3459$ & $236.1362 \pm 0.3833$ \\
\hline $\mathrm{Mg}$ & $140.7630 \pm 0.1940$ & $148.1162 \pm 0.2243$ & $145.8187 \pm 0.2632$ & $168.2284 \pm 0.2198$ & $157.5226 \pm 0.2656$ & $151.7868 \pm 0.2448$ \\
\hline $\mathrm{Mn}$ & $3.3466 \pm 0.0038$ & $4.0584 \pm 0.0058$ & $2.6569 \pm 0.0046$ & $1.6188 \pm 0.0025$ & $1.8393 \pm 0.0031$ & $1.2682 \pm 0.0020$ \\
\hline $\mathrm{Zn}$ & $3.3228 \pm 0.0033$ & $2.3306 \pm 0.0023$ & $4.3794 \pm 0.0047$ & $2.4481 \pm 0.0034$ & $2.8887 \pm 0.0040$ & $3.1565 \pm 0.0045$ \\
\hline $\mathrm{Fe}$ & $11.1698 \pm 0.0089$ & $11.8393 \pm 0.0114$ & $12.3117 \pm 0.0106$ & $16.1482 \pm 0.0130$ & $19.99 \pm 0.0189$ & $16.4342 \pm 0.0115$ \\
\hline $\mathrm{Cu}$ & $0.9691 \pm 0.0022$ & $1.0323 \pm 0.0013$ & $1.0449 \pm 0.0032$ & $1.4498 \pm 0.0017$ & $1.7267 \pm 0.0022$ & $1.2941 \pm 0.0019$ \\
\hline $\mathrm{Li}$ & $0.0484 \pm 0.0001$ & $0.0440 \pm 0.0001$ & $0.0433 \pm 0.0001$ & $0.0497 \pm 0.0001$ & $0.0567 \pm 0.0002$ & $0.0468 \pm 0.0001$ \\
\hline $\mathrm{Be}$ & $0.2932 \pm 0.0001$ & $0.2704 \pm 0.0001$ & $0.2513 \pm 0.0001$ & $0.2253 \pm 0.0001$ & $0.2542 \pm 0.0002$ & $0.2361 \pm 0.0001$ \\
\hline B & $1.4315 \pm 0.0026$ & $1.1423 \pm 0.0018$ & $1.3124 \pm 0.0031$ & $1.2255 \pm 0.0017$ & $1.4512 \pm 0.0025$ & $1.3598 \pm 0.0027$ \\
\hline $\mathrm{Al}$ & $0.8423 \pm 0.0014$ & $3.9631 \pm 0.0061$ & $0.8214 \pm 0.0020$ & $1.5530 \pm 0.0025$ & $2.4421 \pm 0.0039$ & $1.5804 \pm 0.0029$ \\
\hline V & $1.1203 \pm 0.0016$ & $0.8199 \pm 0.0014$ & $1.0216 \pm 0.0015$ & $0.7714 \pm 0.0013$ & $0.8607 \pm 0.0015$ & $1.0850 \pm 0.0010$ \\
\hline $\mathrm{Cr}$ & $0.1360 \pm 0.0004$ & $0.0718 \pm 0.0002$ & $0.1184 \pm 0.0003$ & $0.1031 \pm 0.0003$ & $0.1193 \pm 0.0003$ & $0.1563 \pm 0.0002$ \\
\hline $\mathrm{Ni}$ & $0.4866 \pm 0.0008$ & $0.7302 \pm 0.0011$ & $0.5890 \pm 0.0013$ & $0.1771 \pm 0.0011$ & $0.2330 \pm 0.0010$ & $0.1922 \pm 0.0009$ \\
\hline $\mathrm{Ga}$ & $0.0048 \pm 0.0001$ & $0.0054 \pm 0.0001$ & $0.0044 \pm 0.0001$ & $0.0042 \pm 0.0001$ & $0.0048 \pm 0.0001$ & $0.0041 \pm 0.0001$ \\
\hline $\mathrm{Se}$ & $0.8196 \pm 0.0007$ & $0.7372 \pm 0.0007$ & $0.6692 \pm 0.0002$ & $0.7044 \pm 0.0008$ & $0.7497 \pm 0.0009$ & $0.7041 \pm 0.0008$ \\
\hline $\mathrm{Rb}$ & $0.5622 \pm 0.0003$ & $0.8539 \pm 0.0005$ & $0.3929 \pm 0.0003$ & $0.6514 \pm 0.0008$ & $0.5834 \pm 0.0004$ & $0.4716 \pm 0.0002$ \\
\hline $\mathrm{Sr}$ & $0.3833 \pm 0.0003$ & $0.5270 \pm 0.0003$ & $0.5057 \pm 0.0004$ & $1.0208 \pm 0.0006$ & $0.7438 \pm 0.0005$ & $0.7514 \pm 0.0005$ \\
\hline Mo & $0.1843 \pm 0.0007$ & $0.2127 \pm 0.0005$ & $0.3706 \pm 0.0008$ & $0.3580 \pm 0.0006$ & $0.2710 \pm 0.0005$ & $0.2617 \pm 0.0005$ \\
\hline $\mathrm{Cd}$ & $0.0358 \pm 0.0001$ & $0.0432 \pm 0.0001$ & $0.0257 \pm 0.0001$ & $0.0207 \pm 0.0001$ & $0.0227 \pm 0.0001$ & $0.0376 \pm 0.0001$ \\
\hline $\mathrm{Ba}$ & $0.1098 \pm 0.0001$ & $0.1446 \pm 0.0002$ & $0.1175 \pm 0.0003$ & $0.2320 \pm 0.0004$ & $0.1738 \pm 0.0004$ & $0.1987 \pm 0.0003$ \\
\hline $\mathrm{Tl}$ & $0.0264 \pm 0.0001$ & $0.0245 \pm 0.0001$ & $0.0226 \pm 0.0001$ & $0.0202 \pm 0.0001$ & $0.0220 \pm 0.0001$ & $0.0208 \pm 0.0001$ \\
\hline $\mathrm{Pb}$ & $0.1423 \pm 0.0001$ & $0.1485 \pm 0.0001$ & $0.1078 \pm 0.0001$ & $0.0848 \pm 0.0001$ & $0.0861 \pm 0.0001$ & $0.1500 \pm 0.0001$ \\
\hline $\mathrm{U}$ & $0.0329 \pm 0.0001$ & $0.0309 \pm 0.0001$ & $0.0284 \pm 0.0001$ & $0.0253 \pm 0.0001$ & $0.0273 \pm 0.0001$ & $0.0267 \pm 0.0001$ \\
\hline
\end{tabular}


The intake of phenolic compounds, which are natural miracles in plants, with supplements or natural nutrition, is important for the homeostasis of living organisms [39]. Phenolic substances are known to be the most abundant antioxidant components in legumes [40]. Owing to the high phenolic, saponin and phytate content of chickpea seeds, it was stated that the use of these seeds in the diet was protective in the prevention of chronic and degenerative diseases [27]. The total phenolic content of genotypes was presented in $\mathrm{mg}$ GAE/100 g seed unit (Figure 4). The richest genotypes in terms of total phenolic content were $\mathrm{KG}$ $(218.08 \pm 6.52 \mathrm{mg} \mathrm{GAE} / 100 \mathrm{~g}$ seed) and $\mathrm{KS}$ (215.82 $\pm 4.07 \mathrm{mg}$ GAE/100 g seed) and no statistical difference was determined between these genotypes. Among the genotypes with the highest total phenolic content, DG (201.69 $\pm 4.89 \mathrm{mg}$ GAE/100 g seed) genotype was also in the foreground. Segev et al. [13] indicated that chickpea seeds with coloured coat contained more total phenolic and total flavonoid content than kabuli seeds. However, our results were consistent with the results of the study conducted by Summo et al. [23], who stated that there was no correlation between the phenolic content and coat colour of chickpea seeds.

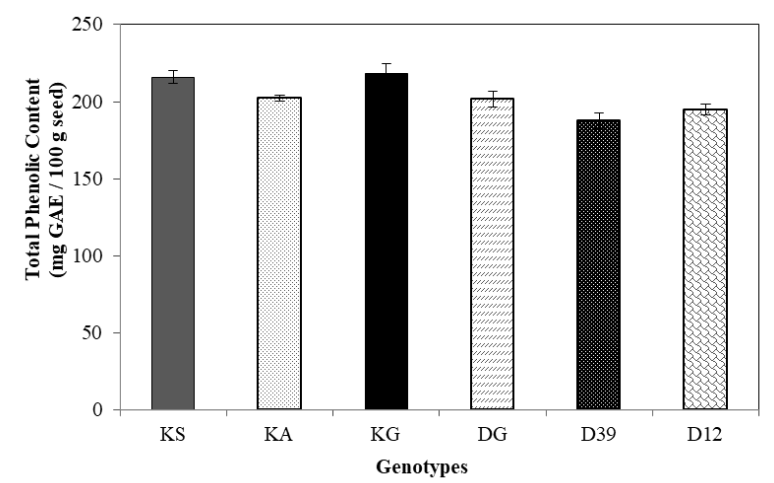

Figure 4. Total phenolic content of kabuli and desi chickpea seeds.

Biskup et al. [39] reported that antibacterial, antioxidant and anti-inflammatory capacities get strong as the total phenolic and flavonoid content increases in plants. The total flavonoid content of genotypes was calculated as $\mathrm{mg} \mathrm{CE} / 100 \mathrm{~g}$ seed unit as given in Figure 5. The richest genotypes in terms of total flavonoid content were listed as KS (342.86 \pm 9.90 $\mathrm{mg} \mathrm{CE} / 100 \mathrm{~g}$ seed $)$ and $\mathrm{KG}(300.95 \pm 11.90 \mathrm{mg} \mathrm{CE} / 100$ $\mathrm{g}$ seed). Seeds with the lowest total flavonoid content belong to D39 (188.57 $\pm 14.29 \mathrm{mg} \mathrm{CE} / 100 \mathrm{~g}$ seeds), just like phenolic levels. Quintero-Soto et al. [41] stated that kabuli type seeds were rich in phenolic contents and desi type seeds were rich in flavonoid compounds. On the other hand, Boye et al. [42] reported that phenol content in desi type seeds is higher than that of kabuli type seeds. However, in this study, it was determined that there was a parallel relationship between phenolic and flavonoid contents of desi and kabuli genotypes. Similarly, Kalefetoğlu Macar et al. [25] showed a very close harmony in phenolic and flavonoid contents of desi and kabuli seeds.

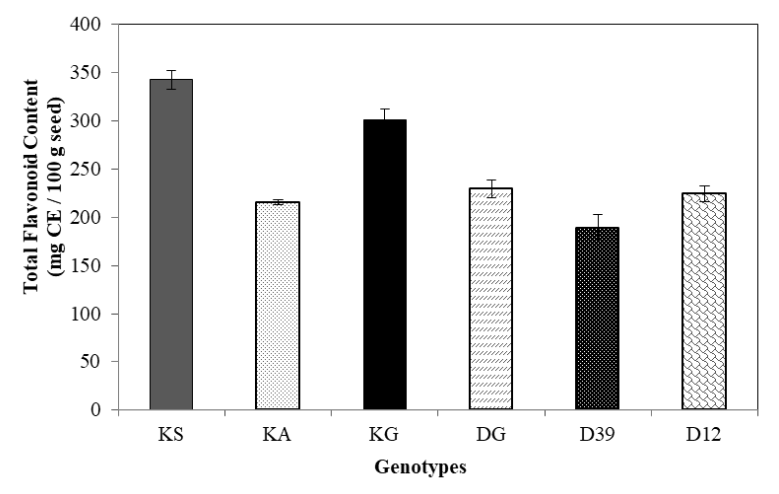

Figure 5. Total flavonoid content of kabuli and desi chickpea seeds.

DPPH assay is a frequently used method for rapidly determining the capacity of antioxidants to carry unstable hydrogen atom to radicals [14]. While DPPH is generally used to calculate free radical scavenging activities for natural products, this method is replaced by different antioxidant capacity determination methods in case of problems such as solubility. ABTS assay is at the top of these methods. The data in the figure shows the average values that cause inhibition of $50 \%$ of the radicals (Figure 6). DPPH and ABTS radical scavenging activity values of each genotype examined showed great parallelism with each other. The most powerful genotypes in terms of these parameters were D39 (desi) and KA (kabuli). There was no statistical difference between KS and DG genotypes, which were the weakest genotypes in terms of radical scavenging activities. It has been stated that the high antioxidant contents in chickpea seeds are effective in preventing diseases caused by free radicals [43]. The parallel relationship between the results of ABTS and DPPH assays detected in our study was found to be compatible with the literature [44]. Zia-UlHaq et al. [14] reported that the high antioxidant capacity in chickpea seeds was associated with the polyphenolic compounds contained in these seeds and these compounds were usually stored under the seed coat. Studies showing the antiradical activities of phenolic compounds contained in legumes against $\mathrm{DPPH}$ and $\mathrm{ABTS}^{+}$radicals are found in the literature $[45,46]$. During the first hydration phase of seed germination, various components of the ROSmediated signal pathways are activated and accumulate. It has been stated that the final stress resistance degree of seedlings can be attributed to the 
permanence of these antioxidant mechanisms activated in seeds [47].

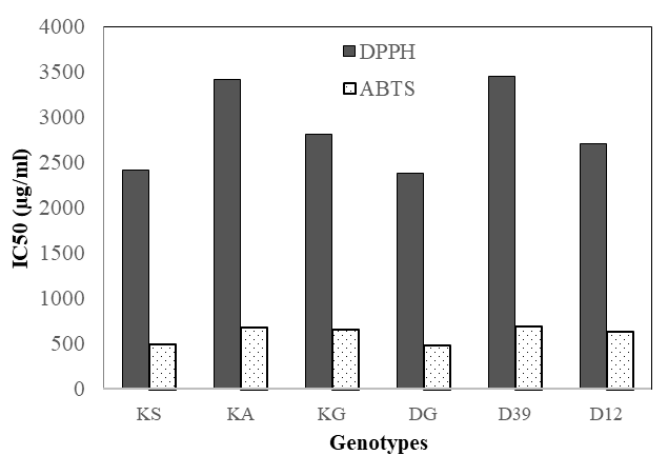

Figure 6. ABTS and DPPH radical scavenging activity of kabuli and desi chickpea seeds.

\section{Conclusion}

With the increasing awareness of consumers about health, the demand for delicious and easily accessible food products with high nutrient content also increases [48]. Another reason why these products are indispensable as functional food is that they have low prices. Chickpea genotypes used in the study were found to be very rich especially in terms of protein content except D39. In contrast to its protein content, the D39 genotype was identified as the carbohydrate richest genotype, despite its small seeds. The superiority of desi genotypes in terms of total antioxidants was expected due to coloured seed coats. In line with the expectation, D39, which is a desi seed, had superiority over other genotypes according to ABTS and DPPH antioxidant tests. However, contrary to the expectations, it could be suggested that KA which is among kabuli genotypes had significant antioxidant capacity considering ABTS and DPPH radical scavenging activities. In terms of phenolic and flavonoid contents, KS and KG was determined to be superior to other genotypes. The results of the total phenolic and total flavonoid analyses used in the study were shown to be in perfect harmony with each other. Due to its rich calcium content, chickpea seeds should be consumed intensively, especially by children and pregnant women. It was determined that desi genotypes, which are not widely consumed in our country, were superior to the kabuli genotypes according to $\mathrm{Ca}, \mathrm{Na}, \mathrm{Mg}, \mathrm{Fe}$ and $\mathrm{Cu}$ levels. On the other hand, $\mathrm{Mn}$ and $\mathrm{Ni}$ contents were significantly higher in kabuli seeds. Mineral element contents in seeds are frequently affected especially by climatic conditions. However, chickpea seeds screened in the present study have been shown to be sufficient to meet people's mineral needs. The current research is an original work with a guiding feature for more detailed seed screening studies. Data have shown that both desi and kabuli types are ideal candidates for functional foods with their low cost and high nutritional value.

\section{Acknowledgment}

The work was supported by grants from Giresun University Scientific Research Unit (project no. FENBAP-A-230218-34). We would like to thank to Dr. Dürdane İnci Mart for providing chickpea seeds.

\section{Conflicts of interest}

The authors state that there is no conflict of interests. 


\section{References}

[1] Jendoubi W., Bouhadida M., Boukteb A. Béji M. and Kharrat M., Fusarium wilt affecting chickpea crop, Agriculture, 7(3) (2017) 23.

[2] Singh R., Sharma P., Varshney R.K., Sharma S.K. and Singh N.K., Chickpea improvement: role of wild species and genetic markers, Biotechnol. Genet. Eng. Rev., 25 (2008) 267-314.

[3] Ahmad P., Abdel Latef A.A., Hashem A., AbdAllah E.F., Gucel S. and Tran L.S.P., Nitric oxide mitigates salt stress by regulating levels of osmolytes and antioxidant enzymes in chickpea, Front. Plant Sci., 7 (2016) 347.

[4] Rybinski W., Banda M., Bocianowski J., Starzycka-Korbas E., Starzycki M. and Nowosad $\mathrm{K}$., Estimation of the physicochemical variation of chickpea seeds (Cicer arietinum L.), Int. Agrophys., 33(1) (2019) 67-80.

[5] Food and Agriculture Organization, Statistical Databases. Available at: http://faostat.fao.org/site/567/default.aspx\#ancor. Retrieved July 8, 2019.

[6] Rasool S., Abdel Latef A.A., Ahmad P., Chickpea: Role and Responses under Abiotic and Biotic Stress. In: Azooz M.M., Ahmad P., (Eds). Legumes under environmental stress: yield, improvement and adaptations, West Sussex: 1st ed. Wiley Blackwell, 2015; 67-79.

[7] Varshney R.K., Thudi M., Roorkiwal M., He W., Upadhyaya H.D., Yang W., Bajaj P., Cubry P., Rathore A., Jian J., Doddamani D., Khan A.W., Garg V., Chitikineni A., Xu D., Gaur P.M., Singh N.P., Chaturvedi S.K., Nadigatla G.V.P.R., Krishnamurthy L., Dixit G.R., Fikre A., Kimurto P.K., Sreeman S.M., Bharadwaj C., Tripathi S., Wang J., Lee S.H., Edwards D., Polavarapu K.K.B., Penmetsa R.V., Crossa J., Nguyen H.T., Siddique K.H.M., Colmer T.D., Suttun T., von Wettberg E., Vigouroux Y., Xu X. and Liu X., Resequencing of 429 chickpea accessions from 45 countries provides insights into genome diversity, domestication and agronomic traits, Nat. Genet., 51(5) (2019) 857-864.

[8] Roy F., Boye J.I. and Simpson B.K., Bioactive proteins and peptides in pulse crops: Pea, chickpea and lentil, Food Res. Int., 43 (2010) 432442.

[9] Özer S., Karaköy T., Toklu F., Baloch F.S., Kilian B. and Özkan H., Nutritional and physicochemical variation in Turkish kabuli chickpea (Cicer arietinum L.) landraces, Euphytica, 175(2) (2010) 237-249.

[10] Kaur R., Grewal S.K., Singh S., Kaur J. and Bhardwaj R.D., Desi and kabuli chickpea cultivars had differential behaviour towards salinity stress tolerance, Biol. Futura, (2020) 110.

[11] Tripathi S., Sridhar V., Jukanti A.K., Suresh K., Rao B.V., Gowda C.L.L. and Gaur P.M., Genetic variability and interrelationships of phenological, physicochemical and cooking quality traits in chickpea, Plant Genet. Res., 10(3) (2012) 194201.

[12] Ullah A., Al-Sadi A.M., Al-Subhi A.M. and Farooq M., Characterization of chickpea genotypes of Pakistani origin for genetic diversity and zinc grain biofortification, J. Sci. Food Agric., (2020).

[13] Segev A., Badani H., Kapulnik Y., Shomer I., Oren-Shamir M. and Galili S., Determination of polyphenols, flavonoids, and antioxidant capacity in colored chickpea (Cicer arietinum L.), J. Food Sci., 75(2) (2010) 115-119.

[14] Zia-Ul-Haq M., Iqbal S., Ahmad S., Imran M., Niaz A. and Bhanger M.I., Nutritional and compositional study of desi chickpea (Cicer arietinum L.) cultivars grown in Punjab, Pakistan, Food Chem., 105(4) (2007) 1357-1363.

[15] Doumas B.T., Waston W.A. and Biggs A.G., Biuret method for quantitative estimation of total protein in serum or plasma, Clin. Chim. Acta, 31 (1971) 87-91.

[16] Hedge J.E., Hofreiter B.T., Carbohydrate chemistry, 17. In: Whistler R.L., Be Miller, J.N., (Eds), New York: Academic Press, 1962; 504.

[17] Marinova D., Ribarova F. and Atanassova M., Total phenolics and total flavonoids in Bulgarian fruits and vegetables, J. Chem. Technol. Metall., 40(3) (2005) 255-260.

[18] Thaipong K., Boonprakob U., Crosby K., Cisneros-Zevallos L. and Byrne D.H., Comparison of ABTS, DPPH, FRAP, and ORAC assays for estimating antioxidant activity from guava fruit extracts, J. Food Compost. Anal., 19(6) (2006) 669-675.

[19] Kaur M. and Singh N., Relationships between selected properties of seeds, flours, and starches from different chickpea cultivars, Int. J. Food Prop., 9(4) (2006) 597-608. 
[20] Sefa-Dedeh S. and Stanley D.W., Textural implications of the microstructure of legumes, Food Technol., 33 (1979) 77-83.

[21] Hossain M.A. and Becker K., Nutritive value and antinutritional factors in different varieties of Sesbania seeds and their morphological fractions, Food Chem., 73(4) (2001) 421-431.

[22] Verma S. and Bhatia S., Analysis of genes encoding seed storage proteins (SSPs) in chickpea (Cicer arietinum L.) reveals co-expressing transcription factors and a seed-specific promoter, Funct. Integr. Genomic., 19(3) (2019) 373-390.

[23] Summo C., De Angelis D., Ricciardi L., Caponio F., Lotti C., Pavan S. and Pasqualone A., Nutritional, physico-chemical and functional characterization of a global chickpea collection, $J$. Food Compost. Anal., 84 (2019) 103306.

[24] Jadhav A., Rayate S., Mhase L., Thudi M., Chitikineni A., Harer P., Jadhav A., Varshney R. and Kulwal P., Marker-trait association study for protein content in chickpea (Cicer arietinum), $J$. Genet., 94 (2015) 279-286.

[25] Macar T.K., Macar O. and Mart D.İ., Variability in some biochemical and nutritional characteristics in desi and Turkish kabuli chickpea (Cicer arietinum L.) types, CBUJOS, 13(3) (2017) 677-680.

[26] Sarika K., Bharadwaj C., Kumar T., Sachdeva S., Tara C., Satyavathi P.K., Jain P.K., Patil B.S., Sarker A. and Prasad S.S., Correlation of seed quality traits with 100 seed weight in chickpea (Cicer arietinum L.) genotypes, IJCS, 7(3) (2019) 4006-4011.

[27] Faridy J.C.M., Stephanie C.G.M., Gabriela M.M.O. and Cristian, JM., Biological activities of chickpea in human health (Cicer arietinum L.). A review, Plant Foods Hum. Nutr., (2020) 1-12.

[28] Swamy S.G., Raja D.S. and Wesley B.J., Susceptibility of stored chickpeas to bruchid infestation as influenced by physico-chemical traits of the grains, J. Stored Prod. Res., 87 (2020) 101583.

[29] Wang R., Gangola M.P., Irvine C., Gaur P.M., Båga M. and Chibbar R.N., Co-localization of genomic regions associated with seed morphology and composition in a desi chickpea (Cicer arietinum L.) population varying in seed protein concentration, Theor. Appl. Genet., 132(4) (2019) 1263-1281.
[30] Wang R., Gangola M.P., Jaiswal S., Gaur P.M., Båga M. and Chibbar R.N., Genotype, environment and their interaction influence seed quality traits in chickpea (Cicer arietinum L.), $J$. Food Compost. Anal., 63 (2017) 21-27.

[31] Bailey R.L., West Jr K.P. and Black R.E., The epidemiology of global micronutrient deficiencies, Ann. Nutr. Metab., 66(2) (2015) 2233.

[32] Miller D.D. and Welch R.M., Food system strategies for preventing micronutrient malnutrition, Food Policy, 42 (2013) 115-128.

[33] Ghribi A., Maklouf I., Blecker C., Attia H. and Besbes S., Nutritional and com-positional study of desi and kabuli chickpea (Cicer arietinum L.) flours from Tunisian cultivars, AFTNSOJ, 1(2) (2015) 38-47.

[34] Wood J.A., Grusak M.A., Nutritional Value of Chickpea. In: Yadav S.S., Redden R.J., Chen W., Sharma B., (Eds). Chickpea breeding and management.,Trowbridge: Cromwell Press, 2007; 101-142.

[35] Kaur K., Grewal S.K., Gill P.S. and Singh S., Comparison of cultivated and wild chickpea genotypes for nutritional quality and antioxidant potential, J. Food Sci. Technol., 56(4) (2019) 1864-1876.

[36] Kayan N. and Adak M.S., Associations of some characters with grain yield in chickpea (Cicer arietinum L.), Pak. J. Bot., 44(1) (2012) 267-272.

[37] Jambunathan R. and Singh, U., Studies on desi and kabuli chickpea (Cicer arietinum L.) cultivars. 3. Mineral and trace elements composition, J. Agric. Food Chem., 29(5) (1981) 1091-1093.

[38] Ray H., Bett K., Tar'an B., Vandenberg A., Thavarajah D. and Warkentin, T., Mineral micronutrient content of cultivars of field pea, chickpea, common bean, and lentil grown in Saskatchewan, Canada, Crop Sci., 54(4) (2014) 1698-1708.

[39] Biskup I., Golonka I., Gamian A. and Sroka Z., Antioxidant activity of selected phenols estimated by ABTS and FRAP methods, Postepy Hig. Med. Dosw., (2013) 67.

[40] Singh B., Singh J.P., Kaur A. and Singh N., Phenolic composition and antioxidant potential of grain legume seeds: A review, Food Res. Int., 101 (2017) 1-16. 
[41] Quintero-Soto M.F., Saracho-Peña A.G., ChavezOntiveros J., Garzon-Tiznado J.A., PinedaHidalgo K.V., Delgado-Vargas F. and LopezValenzuela J.A., Phenolic profiles and their contribution to the antioxidant activity of selected chickpea genotypes from Mexico and ICRISAT collections, Plant Foods Hum. Nutr., 73(2) (2018) 122-129.

[42] Boye J.I., Aksay S., Roufik S., Ribéreau S., Mondor M., Farnworth E. and Rajamohamed S.H., Comparison of the functional properties of pea, chickpea and lentil protein concentrates processed using ultrafiltration and isoelectric precipitation techniques, Food Res. Int., 43(2) (2010) 537-546.

[43] Oberoi H.K., Gupta A.K. and Kaur S., Physicochemical attributes, phenolics and proline content in ninety desi and kabuli chickpea genotypes from different geographical locations, Ind. J. Agric. Biochem., 32(1) (2019) 37-48.

[44] Ettoumi L.Y. and Chibane M., Some physicochemical and functional properties of pea, chickpea and lentil whole flours, Int. Food Res. J., 22(3) (2015) 987.

[45] Xu B.J., Yuan S.H. and Chang S.K.C., Comparative analyses of phenolic composition, antioxidant capacity, and color of cool season legumes and other selected food legumes, J. Food Sci., 72(2) (2007) 167-177.

[46] Amarowicz R., Troszyńska A. and Pegg R.B., Antioxidative and radical scavenging effects of phenolics from Vicia sativum, . Fitoterapia, 79(2) (2008) 121-122.

[47] Islam M.Z., Park B.J., Kang H.M. and Lee Y.T., Influence of selenium biofortification on the bioactive compounds and antioxidant activity of wheat microgreen extract, Food Chem., 309 (2020) 125763.

[48] Bassett C., Boye J., Tyler R. and Oomah B.D., Molecular, functional and processing characteristics of whole pulses and pulse fractions and their emerging food and nutraceutical applications, Food Res. Int., 43(2) (2010) 397398. 